\title{
Anti-Cancer Effects and Mechanisms of Capsaicin in Chili Peppers
}

\author{
Siwei Cao ${ }^{{ }^{*}}$, Huoji Chen ${ }^{*}$, Shijian Xiang1, Junhui Hong1, Lidong Weng1, Hongxia Zhu2\#, \\ Qiang Liu" ${ }^{1 \#}$ \\ ${ }^{1}$ School of Traditional Chinese Medicine, Southern Medical University, Guangzhou, China \\ ${ }^{2}$ Hospital of Integrated Chinese and Western Medicine, Southern Medical University, Guangzhou, China \\ Email: "gzzhx2012@163.com, "gzlq2002@163.com
}

Received 8 October 2015; accepted 6 December 2015; published 9 December 2015

Copyright (C) 2015 by authors and Scientific Research Publishing Inc.

This work is licensed under the Creative Commons Attribution International License (CC BY). http://creativecommons.org/licenses/by/4.0/

(c) (i) Open Access

\begin{abstract}
Cancer is a major cause of morbidity and mortality all over the world and a promising area of cancer research is concentrated on chemoprevention by nutritional compounds. Capsaicin, traditionally used as a food additive and an analgesic, is one of the main pungent ingredients in chili peppers. Recent studies have shown that capsaicin has anti-cancer effects in various types of cancer model. The purpose of this review is to outline the anticarcinogenic effect of capsaicin and its mechanism.
\end{abstract}

\section{Keywords}

Chili Peppers, Capsaicin, Anticarcinogen, Mechanism

\section{Introduction}

The World Cancer Report showed that cancer rates would increase at an alarming rate in the global scope. In this report, cancer rates could further increase by 50\% to 15\% million new cases in the year 2020 [1]. Thus, it is increasing important to find drugs for treating cancer. Recently, capsaicin is proved to have good activity for inhibiting various tumor cells [2]. Besides, capsaicin also decreased the growth of human leukemic cells [3], gastric [4], nasopharyngeal [5], prostate [6], and hepatic carcinoma cells [7] in vitro because of its ability to mediate cell cycle arrest and induce cell apoptosis.

Capsaicinoids are a group of chemical compounds in chili peppers and responsible for stimulated tartly flavor [8] [9]. Capsaicin is the main component of capsaicinoids in chili peppers (Figure 1), followed by dihydrocap-

\footnotetext{
${ }^{*}$ These authors contributed equally to this work.

\#Corresponding authors.
} 
saicin, nordihydrocapsaicin, homodihydrocapsaicin and homocapsaicin. Capsaicin and dihydrocapsaicin, comprises approximately $90 \%$ of capsaicinoids in chili peppers, are the two most potent capsaicinoids and their molecules differ only in the saturation of the acyl group [10] [11]. Capsaicin (trans-8-methyl-N-vanillyl-6-nonenamide) is a crystalline, lipophilic, colorless and odorless alkaloid and it is fat-, alcohol- and oil-soluble. According to the physical-chemical properties, capsaicin can be extracted by the methods of solvent extraction [12], ultrasonic-assisted extraction [13], microwave-assisted extraction [14], pressurised hot water extraction [15], supercritical carbon dioxide extraction [16] and so on. The molecular formula of capsaicin is $\mathrm{C}_{18} \mathrm{H}_{27} \mathrm{NO}_{3}$ and its molecular weight is $305.40 \mathrm{~g} / \mathrm{mol}$. First crystallized in 1876 by Tresh, who named it, capsaicin’s molecular structure was resolved by Nelson and Dawson in 1919. Till now, many researches have demonstrated that capsaicinoids, and capsaicin particularly, have a broad variety of biological and physiological activities, such as pain relief [17], the anti-obesity effect [18], the anti-inflammatory effect [19], the cardiovascular effect [20] and especially the anti-tumor activity which has increasingly attracted researchers' interest.

In this paper, we aim to provide a review of the anti-cancer effects of capsaicin and the mechanisms behind it in recent five years, since capsaicin has a good prospect in antitumor and it is meaningful and helpful to find medicines for cancer treatment.

\section{Anticarcinogenic Effects}

\subsection{Prostatic Cancer}

Prostate cancer is a common malignancy in male. As one of the natural product, capsaicin, the active compound in chili peppers, has been shown to inhibit the proliferation of prostate cancer in vitro and in vivo [21]. Natalieet et al. indicated that capsaicin inhibit of $\mathrm{NF} \kappa \mathrm{B}$ signaling in the prostatic cancer by the role a radio-sensitzing agent [22]. Other study revealed that capsaicin promotes the secretion of TNF- $\alpha$-stimulated IL-6 in PC-3 cells and induces the expression of IL-6 through TRPV1, ERK, PKC-a, PI3K/Akt activation [23]. Interestingly, the latest study demonstrated that capsaicin negatively regulates the activity of androgen receptor at the mRNA and protein levels by restoring miR-449a profiling. Additionally, it may increase the sensitivity of prostate cancer through increasing expression of miR-449a in capsaicin treatment. As a consequence, capsaicin may possibly developed as a drug for the treatment of prostate cancer [24].

\subsection{Colorectal Cancer}

Colorectal cancer is a key public health issues in western countries and the third leading cause of cancer-related death in the United States [25]. A number of case-control and cohort studies have demonstrated an inverse relationship between the consumption of vegetables and colorectal cancer [26]. Among common vegetables selected on the basis of consumption per capita data in the United States, red chili pepper showed very high anti-proliferative and anti-oxidant activity [27]. Several studies were also proven that capsaicin might inhibit the growth of human colorectal cancer cells.

The study by Lee et al. elucidated that capsaicin might prevent the growth of human colorectal cancer cells by suppressing $\beta$-catenin/TCF-dependent pathways via multiple mechanisms, including suppression of $\beta$-catenin transcription, activation of proteosomal degradation of $\beta$-catenin, and disruption of $\beta$-catenin/TCF-4 interactions [28]. In addition, Yang et al. demonstrated that therapy with high-concentration of capsaicin $(\geq 200 \mu \mathrm{M}$ for SW480 and CT-26 cell lines; $\geq 25 \mu \mathrm{M}$ for HCT116 cell line) inhibited colorectal cancer cell proliferation in a
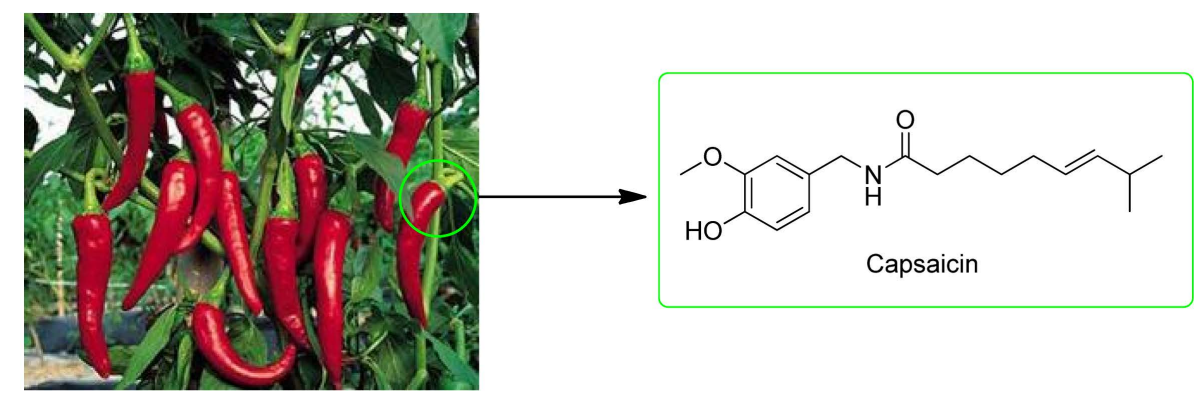

Figure 1. The structure of capsaicin. 
dose-dependent manner [29]. The current study evaluated the potential synergistic effects of capsaicin, which suggested that capsaicin and DIM work synergistically to inhibit cell proliferation and induce apoptosis in colorectal cancer through modulating transcriptional activity of NF- $\kappa \mathrm{B}$, p53, and target genes associated with apoptosis [30].

\subsection{Lung Cancer}

Lung cancer, the second most frequent cancer, ranks first as a cause of mortality worldwide among the men and women [31] [32]. It becomes a serious health problem in most countries and its occurrence rate is prolifically increasing [33]. Smoking is the leading cause of lung cancer. Tobacco smoke contains over 60 known carcinogens. Among the carcinogens, the polycyclic aromatic hydrocarbons (PAHs) such as benzo(a)pyrene [B(a)P], play a significant role in lung carcinogenesis [34]. In some research, capsaicin has been reported to induce tumor cells apoptosis and restrict benzo(a)pyrene induced lung tumorigenesis in Swiss albino mice [35] [36].

There are two major types: non-small cell lung cancer, which is the most common, and small cell lung cancer, which spreads more quickly.

Non-small cell lung cancer accounts for $80 \%$ of all lung cancers. Its treatment is intrinsically resistant to chemotherapy or irradiation therapy. Previous research has shown that several pro-angiogenic factors such as vascular endothelial growth factor (VEGF) are highly expressed in the tumor microenvironment and strongly induce tumor angiogenesis which is essential for the growth and metastasis of non-small cell lung cancer [37]. Results proposed by Chakraborty et al. show that capsaicin induces activation of p53-SMAR1 auto-regulatory loop and down-regulates VEGF in non-small cell lung cancer to restrain angiogenesis, and this may offer the panorama of exclusively targeting pro-angiogenic factors and pathways to achieve more efficient and cogent lung cancer therapy [38].

Small cell lung cancer, represents $13 \%$ of all lung cancer cases, is a neuroendocrine tumor characterized by early dissemination and rapid metastasis [39]. It is the most aggressive form of lung cancer, with an overall 5 -year survival time of less than 5\% [40]. The identification of dietary compounds that can decrease the growth of small cell lung cancer could foster the hope of novel therapies for this disease [41]. Recent report from Lau's group suggested that capsaicin induces apoptosis of human small cell lung cancer cells through the TRPV6 and downstream calpain pathway, which revealed TRPV6 might be a useful molecular target for the treatment of human small cell lung cancer [41].

\subsection{Gastric Cancer}

Gastric cancer is a malignancy that occurs from the lining of the stomach. Though there has been a remarkable decrease in the number of people diagnosed with gastric cancer in the past decades worldwide, it is the fourth most common cause of cancer and the second leading cause of cancer-related mortality in the world, causing about 900,000 deaths worldwide per year [42]. Many studies have suggests that capsaicin can induce cell-cycle arrest or apoptosis or inhibit proliferation in a variety of cancer cells and it has a potential to chemopreventive activities [43]. Possible chemosensitizing effect of capsaicin was proved by Ogunc's group, when capsaicin and 5-FU are combined, the inhibitory effect was significantly higher than that of 5-FU when used individually [44]. SEON et al. demonstrated that capsaicin induced apoptosis in human gastric cancer cells and may serve as an anti-tumorigenic agent in human gastric cancer [2]. Likewise, other studies showed that capsaicin displays apoptotic activity of cisplatin-resistant gastric cancer cells by causing degradation of cisplatin-inducible Aurora-A protein [4] [45].

\subsection{Pancreatic Cancer}

Pancreatic cancer, one of the most deadliest of all the solid malignancies, is the fourth leading cause of cancer death in the United States [46] [47] and the eighth-leading cause of cancer related mortalily in China [48]. Owing to early symptoms are not easily diagnosed and its strongly aggressive nature, only $10 \%-20 \%$ of pancreatic cancers can be resected through surgery [49]. For unresectable pancreatic cancers, administration of gemcitabine chemotherapy is considered as the current standard treatment [50]. However, gemcitabine treatment results in an objective cancer response rate of less than 20\% [50] [51] due to the inherent resistance to chemotherapeutic agents and its toxicity [52] [53]. Therefore, efforts have been directed to find novel drugs for the sake of im- 
proving the survival rate and the prognosis of this potentially fatal disease [54].

Capsaicin, the active compound in chili peppers, has been proven to induce apoptosis in various tumors so as to enhance the therapeutic effects of chemotherapy in pancreatic cancer [55]-[57]. Several reports indicate that capsaicin exerts its inhibitory effect on proliferation of pancreatic cancer cells via ERS-mediated apoptotic pathway or the phosphoinositide 3-kinase/Akt pathway [55] [58]. Other studies elucidated that capsaicin causes ROS generation through mitochondria and depleted intracellular antioxidants resulting in mitochondrial damage and apoptosis in pancreatic cancer cells, while normal pancreatic epithelial cells were resistant to the effects of capsaicin [59]. Oppositely, results of Skrzypski et al. suggest that capsaicin induces cytotoxicity by disturbing mitochondrial potential, and inhibits ATP synthesis in NET cells. Stimulation of ROS generation by capsaicin appears to be a secondary effect, not related to capsaicin-induced cytotoxicity [60].

\section{Prospects and Discussions}

Capsaicin has various anti-cancer effects, which have been put forward for a period of time. But currently it still stays in the stage of animals experiment and in vitro experiment. And there is a long way to go before entering the clinical stage. Besides, some reports that capsaicin has carcinogenic effects, such as enhancing tumor cell proliferation and migration by the treatment with low-concentration of capsaicin [29] [61], which also limit its clinical uses. So the security of capsaicin should be evaluated with epidemiological research. The chemical synthesis and structural modification can be applied to reduce the harmful effects of capsaicin and improve its anticancer effect. Furthermore, there is a necessity to continue to study the anti-cancer activity of capsaicin in other cancer. We could believe that capsaicin can bring new hope to cancer patients, and capsaicin will have a bright future and broad market.

\section{References}

[1] WHO (2014) Global Cancer Rates Could Increase by 50\% to 15 Million by 2020. http://www.who.int/mediacentre/news/releases/2003/pr27/en

[2] Park, S.Y., Kim, J.Y., Lee, S.M., Jun, C.H., Cho, S.B., Park, C.H., Joo, Y.E., Kim, H.S., Choi, S.K. and Rew, J.S. (2014) Capsaicin Induces Apoptosis and Modulates MAPK Signaling in Human Gastric Cancer Cells. Molecular Medicine Reports, 9, 499-502.

[3] Ito, K., Nakazato, T., Yamato, K., Miyakawa, Y., Yamada, T., Hozumi, N., Segawa, K., Ikeda, Y. and Kizaki, M. (2004) Induction of Apoptosis in Leukemic Cells by Homovanillic Acid Derivative, Capsaicin, through Oxidative Stress: Implication of Phosphorylation of p53 at Ser-15 Residue by Reactive Oxygen Species. Cancer Research, 64, 1071-1078. http://dx.doi.org/10.1158/0008-5472.CAN-03-1670

[4] Huh, H.C., Lee, S.Y., Lee, S.K., Park, N.H. and Han, I.S. (2011) Capsaicin Induces Apoptosis of Cisplatin-Resistant Stomach Cancer Cells by Causing Degradation of Cisplatin-Inducible Aurora-A Protein. Nutrition and Cancer, 63, 1095-1103. http://dx.doi.org/10.1080/01635581.2011.607548

[5] Ip, S.W., Lan, S.H., Lu, H.F., Huang, A.C., Yang, J.S., Lin, J.P., Huang, H.Y., Lien, J.C., Ho, C.C., Chiu, C.F., Wood, W. and Chung, J.G. (2012) Capsaicin Mediates Apoptosis in Human Nasopharyngeal Carcinoma NPC-TW 039 Cells through Mitochondrial Depolarization and Endoplasmic Reticulum Stress. Human \& Experimental Toxicology, 31, 539-549. http://dx.doi.org/10.1177/0960327111417269

[6] Mori, A., Lehmann, S., O’Kelly, J., Kumagai, T., Desmond, J.C., Pervan, M., McBride, W.H., Kizaki, M. and Koeffler, H.P. (2006) Capsaicin, a Component of Red Peppers, Inhibits the Growth of Androgen-Independent, p53 Mutant Prostate Cancer Cells. Cancer Research, 66, 3222-3229. http://dx.doi.org/10.1158/0008-5472.CAN-05-0087

[7] Huang, S.P., Chen, J.C., Wu, C.C., Chen, C.T., Tang, N.Y., Ho, Y.T., Lo, C., Lin, J.P., Chung, J.G. and Lin, J.G. (2009) Capsaicin-Induced Apoptosis in Human Hepatoma HepG2 Cells. Anticancer Research, 29, 165-174.

[8] Govindarajan, V.S. and Sathyanarayana, M.N. (1991) Capsicum-Production, Technology, Chemistry, and Quality. Part V. Impact on Physiology, Pharmacology, Nutrition, and Metabolism; Structure, Pungency, Pain, and Desensitization Sequences. Critical Reviews in Food Science and Nutrition, 29, 435-474. http://dx.doi.org/10.1080/10408399109527536

[9] Reyes-Escogido, M.L., Gonzalez-Mondragon, E.G. and Vazquez-Tzompantzi, E. (2011) Chemical and Pharmacological Aspects of Capsaicin. Molecules, 16, 1253-1270. http://dx.doi.org/10.3390/molecules16021253

[10] Bernal, M.A., Calderon, A.A., Pedreno, M.A., Ferrer, M.A., Merino, D.C.F. and Ros, B.A. (1994) Purification of a Basic Peroxidase Isoenzyme from Capsicum Fruits and the Immunoinhibition of Its Capsaicin Oxidation Capacity by Antibodies Raised against Horseradish Peroxidase. Zeitschrift für Lebensmittel-Untersuchung und Forschung, 199, 240- 
242. http://dx.doi.org/10.1007/BF01193453

[11] Walpole, C.S., Bevan, S., Bloomfield, G., Breckenridge, R., James, I.F., Ritchie, T., Szallasi, A., Winter, J. and Wrigglesworth, R. (1996) Similarities and Differences in the Structure-Activity Relationships of Capsaicin and Resiniferatoxin Analogues. Journal of Medicinal Chemistry, 39, 2939-2952. http://dx.doi.org/10.1021/jm960139d

[12] Chinn, M.S., Sharma-Shivappa, R.R. and Cotter, J.L. (2011) Solvent Extraction and Quantification of Capsaicinoids from Capsicum chinense. Food and Bioproducts Processing, 89, 340-345. http://dx.doi.org/10.1016/j.fbp.2010.08.003

[13] Deng, X. (2012) Optimization of Ultrasonic-Assisted Extraction Procedure of Capsaicinoids from Chili Peppers Using Orthogonal Array Experimental Design. African Journal of Biotechnology, 11, 13153-13161. http://dx.doi.org/10.5897/ajb12.752

[14] Nazari, F., Ebrahimi, S.N., Talebi, M., Rassouli, A. and Bijanzadeh, H.R. (2007) Multivariate Optimisation of Microwave-Assisted Extraction of Capsaicin from Capsicum frutescens L. and Quantitative Analysis by 1H-NMR. Phytochemical Analysis, 18, 333-340. http://dx.doi.org/10.1002/pca.987

[15] Bajer, T., Bajerová, P., Kremr, D., Eisner, A. and Ventura, K. (2015) Central Composite Design of Pressurised Hot Water Extraction Process for Extracting Capsaicinoids from Chili Peppers. Journal of Food Composition and Analysis, 40, 32-38. http://dx.doi.org/10.1016/j.jfca.2014.12.008

[16] de Aguiar, A.C., Sales, L.P., Coutinho, J.P., Barbero, G.F., Godoy, H.T. and Martínez, J. (2013) Supercritical Carbon Dioxide Extraction of Capsicum Peppers: Global Yield and Capsaicinoid Content. The Journal of Supercritical Fluids, 81, 210-216. http://dx.doi.org/10.1016/j.supflu.2013.05.008

[17] Maihofner, C. and Heskamp, M.L. (2013) Prospective, Non-Interventional Study on the Tolerability and Analgesic Effectiveness over 12 Weeks after a Single Application of Capsaicin 8\% Cutaneous Patch in 1044 Patients with Peripheral Neuropathic Pain: First Results of the QUEPP Study. Current Medical Research and Opinion, 29, 673-683. http://dx.doi.org/10.1185/03007995.2013.792246

[18] Baboota, R.K., Murtaza, N., Jagtap, S., Singh, D.P., Karmase, A., Kaur, J., Bhutani, K.K., Boparai, R.K., Premkumar, L.S., Kondepudi, K.K. and Bishnoi, M. (2014) Capsaicin-Induced Transcriptional Changes in Hypothalamus and Alterations in Gut Microbial Count in High Fat Diet Fed Mice. The Journal of Nutritional Biochemistry, 25, 893-902. http://dx.doi.org/10.1016/j.jnutbio.2014.04.004

[19] Toyoda, T., Shi, L., Takasu, S., Cho, Y., Kiriyama, Y., Nishikawa, A., Ogawa, K., Tatematsu, M. and Tsukamoto, T. (2015) Anti-Inflammatory Effects of Capsaicin and Piperine on Helicobacter Pylori-Induced Chronic Gastritis in Mongolian Gerbils. Helicobacter, Epub Ahead of Print.

[20] Qin, S.L., Liu, S.L. and Wang, R.R. (2008) Protective Effect of Capsaicin on Against Myocardial Ischemia-Reperfusion Injury of Rat in Vivo. Journal of Sichuan University (Medical Science Edition), 39, 550-554.

[21] Venier, N.A., Yamamoto, T., Sugar, L.M., Adomat, H., Fleshner, N.E., Klotz, L.H. and Venkateswaran, V. (2015) Capsaicin Reduces the Metastatic Burden in the Transgenic Adenocarcinoma of the Mouse Prostate Model. Prostate, 75, 1300-1311. http://dx.doi.org/10.1002/pros.23013

[22] Venier, N.A., Colquhoun, A.J., Sasaki, H., Kiss, A., Sugar, L., Adomat, H., Fleshner, N.E., Klotz, L.H. and Venkateswaran, V. (2015) Capsaicin: A Novel Radio-Sensitizing Agent for Prostate Cancer. The Prostate, 75, 113-125. http://dx.doi.org/10.1002/pros.22896

[23] Malagarie-Cazenave, S., Olea-Herrero, N., Vara, D., Morell, C. and Díaz-Laviada, I. (2011) The Vanilloid Capsaicin Induces IL-6 Secretion in Prostate PC-3 Cancer Cells. Cytokine, 54, 330-337. http://dx.doi.org/10.1016/j.cyto.2011.03.010

[24] Zheng, L., Chen, J., Ma, Z., Liu, W., Yang, F., Yang, Z., Wang, K., Wang, X., He, D. and Li, L. (2015) Capsaicin Causes Inactivation and Degradation of the Androgen Receptor by Inducing the Restoration of miR-449a in Prostate Cancer. Oncology Reports, 34, 1027-1034. http://dx.doi.org/10.3892/or.2015.4055

[25] Parkin, D.M., Bray, F., Ferlay, J. and Pisani, P. (2005) Global Cancer Statistics, 2002. CA: A Cancer Journal for Clinicians, 55, 74-108. http://dx.doi.org/10.3322/canjclin.55.2.74

[26] No Authors Listed (1998) Nutritional Aspects of the Development of Cancer. Report of the Working Group on Diet and Cancer of the Committee on Medical Aspects of Food and Nutrition Policy. Reports on Health and Social Subjects (London), 48, 1-274.

[27] Chu, Y.F., Sun, J., Wu, X. and Liu, R.H. (2002) Antioxidant and Antiproliferative Activities of Common Vegetables. Journal of Agricultural and Food Chemistry, 50, 6910-6916. http://dx.doi.org/10.1021/jf020665f

[28] Lee, S., Richardson, R.L., Dashwood, R.H. and Baek, S.J. (2012) Capsaicin Represses Transcriptional Activity of $\beta$ Catenin in Human Colorectal Cancer Cells. The Journal of Nutritional Biochemistry, 23, 646-655. http://dx.doi.org/10.1016/j.jnutbio.2011.03.009

[29] Yang, J., Li, T.Z., Xu, G.H., Luo, B.B., Chen, Y.X. and Zhang, T. (2013) Low-Concentration Capsaicin Promotes Colorectal Cancer Metastasis by Triggering ROS Production and Modulating Akt/mTOR and STAT-3 Pathways. Neop- 
lasma, 60, 364-372. http://dx.doi.org/10.4149/neo_2013_048

[30] Clark, R., Lee, J. and Lee, S.H. (2015) Synergistic Anticancer Activity of Capsaicin and 3,3'-Diindolylmethane in Human Colorectal Cancer. Journal of Agricultural and Food Chemistry, 63, 4297-4304. http://dx.doi.org/10.1021/jf506098s

[31] Magesh, V., Singh, J.P., Selvendiran, K., Ekambaram, G. and Sakthisekaran, D. (2006) Antitumour Activity of Crocetin in Accordance to Tumor Incidence, Antioxidant Status, Drug Metabolizing Enzymes and Histopathological Studies. Molecular and Cellular Biochemistry, 287, 127-135. http://dx.doi.org/10.1007/s11010-005-9088-0

[32] Siegel, R., Naishadham, D. and Jemal, A. (2013) Cancer Statistics, 2013. CA: A Cancer Journal for Clinicians, 63, 1130. http://dx.doi.org/10.3322/caac.21166

[33] Anandakumar, P., Kamaraj, S., Jagan, S., Ramakrishnan, G., Asokkumar, S., Naveenkumar, C., Raghunandhakumar, S. and Devaki, T. (2012) Capsaicin Inhibits Benzo(a)pyrene-Induced Lung Carcinogenesis in an in Vivo Mouse Model. Inflammation Research, 61, 1169-1175. http://dx.doi.org/10.1007/s00011-012-0511-1

[34] Hecht, S.S., Upadhyaya, P., Wang, M., Bliss, R.L., McIntee, E.J. and Kenney, P.M. (2002) Inhibition of Lung Tumorigenesis in A/J Mice by $N$-Acetyl-S-( $N$-2-phenethylthiocarbamoyl)-L-cysteine and myo-Inositol, Individually and in Combination. Carcinogenesis, 23, 1455-1461. http://dx.doi.org/10.1093/carcin/23.9.1455

[35] Anandakumar, P., Kamaraj, S., Jagan, S., Ramakrishnan, G. and Devaki, T. (2013) Capsaicin Provokes Apoptosis and Restricts Benzo(a)pyrene Induced Lung Tumorigenesis in Swiss Albino Mice. International Immunopharmacology, 17, 254-259. http://dx.doi.org/10.1016/j.intimp.2013.05.015

[36] Anandakumar, P., Kamaraj, S., Jagan, S., Ramakrishnan, G., Asokkumar, S., Naveenkumar, C., Raghunandhakumar, S., Vanitha, M.K. and Devaki, T. (2015) The Anticancer Role of Capsaicin in Experimentally Induced Lung Carcinogenesis. Journal of Pharmacopuncture, 18, 19-25. http://dx.doi.org/10.3831/KPI.2015.18.011

[37] Bergers, G. and Benjamin, L.E. (2003) Angiogenesis: Tumorigenesis and the Angiogenic Switch. Nature Reviews Cancer, 3, 401-410. http://dx.doi.org/10.1038/nrc1093

[38] Chakraborty, S., Adhikary, A., Mazumdar, M., Mukherjee, S., Bhattacharjee, P., Guha, D., Choudhuri, T., Chattopadhyay, S., Sa, G., Sen, A. and Das, T. (2014) Capsaicin-Induced Activation of p53-SMAR1 Auto-Regulatory Loop Down-Regulates VEGF in Non-Small Cell Lung Cancer to Restrain Angiogenesis. PLoS ONE, 9, e99743. http://dx.doi.org/10.1371/journal.pone.0099743

[39] Kallianos, A., Rapti, A., Zarogoulidis, P., Tsakiridis, K., Mpakas, A., Katsikogiannis, N., Kougioumtzi, I., Li, Q., Huang, H., Zaric, B., Perin, B., Courcoutsakis, N. and Zarogoulidis, K. (2013) Therapeutic Procedure in Small Cell Lung Cancer. Journal of Thoracic Disease, 5, S420-S424.

[40] Goldberg, S.B., Willers, H. and Heist, R.S. (2013) Multidisciplinary Management of Small Cell Lung Cancer. Surgical Oncology Clinics of North America, 22, 329-343. http://dx.doi.org/10.1016/j.soc.2012.12.002

[41] Lau, J.K., Brown, K.C., Dom, A.M., Witte, T.R., Thornhill, B.A., Crabtree, C.M., Perry, H.E., Brown, J.M., Ball, J.G., Creel, R.G., Damron, C.L., Rollyson, W.D., Stevenson, C.D., Hardman, W.E., Valentovic, M.A., Carpenter, A.B. and Dasgupta, P. (2014) Capsaicin Induces Apoptosis in Human Small Cell Lung Cancer via the TRPV6 Receptor and the Calpain Pathway. Apoptosis, 19, 1190-1201. http://dx.doi.org/10.1007/s10495-014-1007-y

[42] Jemal, A., Bray, F., Center, M.M., Ferlay, J., Ward, E. and Forman, D. (2011) Global Cancer Statistics. CA: A Cancer Journal for Clinicians, 61, 69-90. http://dx.doi.org/10.3322/caac.20107

[43] Liao, F., Yang, Z., Lu, X., Guo, X. and Dong, W. (2013) Sinomenine Sensitizes Gastric Cancer Cells to 5-Fluorouracil in Vitro and in Vivo. Oncology Letters, 6, 1604-1610.

[44] Meral, O., Alpay, M., Kismali, G., Kosova, F., Cakir, D.U., Pekcan, M., Yigit, S. and Sel, T. (2014) Capsaicin Inhibits Cell Proliferation by Cytochrome C Release in Gastric Cancer Cells. Tumor Biology, 35, 6485-6492. http://dx.doi.org/10.1007/s13277-014-1864-6

[45] López-Carrillo, L., Camargo, M.C., Schneider, B.G., Sicinschi, L.A., Hernández-Ramírez, R.U., Correa, P. and Cebrian, M.E. (2012) Capsaicin Consumption, Helicobacter pylori CagA Status and IL1B-31C>T Genotypes: A Host and Environment Interaction in Gastric Cancer. Food and Chemical Toxicology, 50, 2118-2122. http://dx.doi.org/10.1016/j.fct.2012.02.043

[46] Vincent, A., Herman, J., Schulick, R., Hruban, R.H. and Goggins, M. (2011) Pancreatic Cancer. The Lancet, 378, 607620. http://dx.doi.org/10.1016/S0140-6736(10)62307-0

[47] Raimondi, S., Maisonneuve, P. and Lowenfels, A.B. (2009) Epidemiology of Pancreatic Cancer: An Overview. Nature Reviews Gastroenterology \& Hepatology, 6, 699-708. http://dx.doi.org/10.1038/nrgastro.2009.177

[48] Wang, L., Yang, G.H., Lu, X.H., Huang, Z.J. and Li, H. (2003) Pancreatic Cancer Mortality in China (1991-2000). World Journal of Gastroenterology, 9, 1819-1823. http://dx.doi.org/10.3748/wjg.v9.i8.1819

[49] Li, D., Xie, K., Wolff, R. and Abbruzzese, J.L. (2004) Pancreatic Cancer. The Lancet, 363, 1049-1057. 
http://dx.doi.org/10.1016/S0140-6736(04)15841-8

[50] Stathis, A. and Moore, M.J. (2010) Advanced Pancreatic Carcinoma: Current Treatment and Future Challenges. Nature Reviews Clinical Oncology, 7, 163-172. http://dx.doi.org/10.1038/nrclinonc.2009.236

[51] Arends, J.J., Sleeboom, H.P., Leys, M.B., Ten, B.H.D., de Jong, R.S., Smit, J.M., Nortier, J.W. and Tesselaar, M.E. (2005) A Phase II Study of Raltitrexed and Gemcitabine in Patients with Advanced Pancreatic Carcinoma. British Journal of Cancer, 92, 445-448. http://dx.doi.org/10.1038/sj.bjc.6602368

[52] Andersson, R., Aho, U., Nilsson, B.I., Peters, G.J., Pastor-Anglada, M., Rasch, W. and Sandvold, M.L. (2009) Gemcitabine Chemoresistance in Pancreatic Cancer: Molecular Mechanisms and Potential Solutions. Scandinavian Journal of Gastroenterology, 44, 782-786. http://dx.doi.org/10.1080/00365520902745039

[53] Hartel, M., di Mola, F.F., Selvaggi, F., Mascetta, G., Wente, M.N., Felix, K., Giese, N.A., Hinz, U., Di Sebastiano, P., Buchler, M.W. and Friess, H. (2006) Vanilloids in Pancreatic Cancer: Potential for Chemotherapy and Pain Management. Gut, 55, 519-528. http://dx.doi.org/10.1136/gut.2005.073205

[54] Jemal, A., Siegel, R., Xu, J. and Ward, E. (2010) Cancer Statistics, 2010. CA: A Cancer Journal for Clinicians, 60, 277-300. http://dx.doi.org/10.3322/caac.20073

[55] Zhang, J.H., Lai, F.J., Chen, H., Luo, J., Zhang, R.Y., Bu, H.Q., Wang, Z.H., Lin, H.H. and Lin, S.Z. (2013) Involvement of the Phosphoinositide 3-Kinase/Akt Pathway in Apoptosis Induced by Capsaicin in the Human Pancreatic Cancer Cell Line PANC-1. Oncology Letters, 5, 43-48.

[56] Wei, W.T., Chen, H., Ni, Z.L., Liu, H.B., Tong, H.F., Fan, L., Liu, A., Qiu, M.X., Liu, D.L., Guo, H.C., Wang, Z.H. and Lin, S.Z. (2011) Antitumor and Apoptosis-Promoting Properties of Emodin, an Anthraquinone Derivative from Rheum officinale Baill, against Pancreatic Cancer in Mice via Inhibition of Akt Activation. International Journal of Oncology, 39, 1381-1390.

[57] Wei, W.T., Chen, H., Wang, Z.H., Ni, Z.L., Liu, H.B., Tong, H.F., Guo, H.C., Liu, D.L. and Lin, S.Z. (2012) Enhanced Antitumor Efficacy of Gemcitabine by Evodiamine on Pancreatic Cancer via Regulating PI3K/Akt Pathway. International Journal of Biological Sciences, 8, 1-14. http://dx.doi.org/10.7150/ijbs.8.1

[58] Lin, S., Zhang, J., Chen, H., Chen, K., Lai, F., Luo, J., Wang, Z., Bu, H., Zhang, R., Li, H. and Tong, H. (2013) Involvement of Endoplasmic Reticulum Stress in Capsaicin-Induced Apoptosis of Human Pancreatic Cancer Cells. Evidence-Based Complementary and Alternative Medicine, 2013, 1-12.

[59] Pramanik, K.C., Boreddy, S.R. and Srivastava, S.K. (2011) Role of Mitochondrial Electron Transport Chain Complexes in Capsaicin Mediated Oxidative Stress Leading to Apoptosis in Pancreatic Cancer Cells. PLoS ONE, 6, e20151. http://dx.doi.org/10.1371/journal.pone.0020151

[60] Skrzypski, M., Sassek, M., Abdelmessih, S., Mergler, S., Grötzinger, C., Metzke, D., Wojciechowicz, T., Nowak, K.W. and Strowski, M.Z. (2014) Capsaicin Induces Cytotoxicity in Pancreatic Neuroendocrine Tumor Cells via Mitochondrial Action. Cellular Signalling, 26, 41-48. http://dx.doi.org/10.1016/j.cellsig.2013.09.014

[61] Liu, N.C., Hsieh, P.F., Hsieh, M.K., Zeng, Z.M., Cheng, H.L., Liao, J.W. and Chueh, P.J. (2012) Capsaicin-Mediated tNOX (ENOX2) Up-Regulation Enhances Cell Proliferation and Migration in Vitro and in Vivo. Journal of Agricultural and Food Chemistry, 60, 2758-2765. http://dx.doi.org/10.1021/jf204869w 